\title{
OCCURRENCE OF DOMESTIC ELDER ABUSE
}

\author{
Cheila Cristina Leonardo de Oliveira Gaioli ${ }^{1}$
} Rosalina Aparecida Partezani Rodrigues ${ }^{2}$

Gaioli CCLO, Rodrigues RAP. Occurrence of domestic elder abuse. Rev Latino-am Enfermagem 2008 maiojunho; 16(3):465-70.

This study aimed to verify the occurrence of domestic abuse against male and female elderly people in 2006, using medical examination reports, and to identify aggressors and injuries caused, in accordance with the International Classification of Diseases (ICD - 10). The sample consisted of 87 male and female elderly persons aged 60 or more, who lived in Ribeirão Preto-SP, Brazil, filed a complaint at a Police Station in 2002. Medical legal exam reports were consulted. The data were analyzed by means of descriptive statistics. Domestic abuse occurred more frequently among men (58.6\%) who were attacked by family members, such as children, grandchildren, sons-in-law and daughters-in-law (47.1\%). With respect to the kinds of injuries, 33.5\% manifested unspecified superficial shoulder and arm trauma. Elder abuse is becoming increasingly clear in society, thus acquiring social and public health dimensions.

DESCRIPTORS: elder abuse; domestic violence

\section{OCURRENCIA DE MALTRATOS A LOS ANCIANOS EN EL DOMICILIO}

La finalidad de este estudio fue verificar la ocurrencia de maltratos a los ancianos, de ambos sexos, en sus residencias, en laudos de exámenes de cuerpo de delito, e identificar ofensores y lesiones causadas, según la Clasificación Internacional de Enfermedades (CID - 10), en 2006. La muestra consistió en 87 ancianos, de ambos sexos, con edad de 60 años o más, residentes en el municipio de Ribeirao Preto, SP, que presentaron Denuncia en las Comisarías de Policía en 2002. Se consultaron dictámenes de exámenes de cuerpo del delito; el análisis utilizado fue la estadística descriptiva. Los maltratos en la residencia ocurrieron con mayor frecuencia entre ancianos del sexo masculino (58,6\%), que fueron ofendidos por familiares como hijos, nietos, yernos $y$ nueras (47,1\%). En cuanto a los tipos de lesiones sufridas, el 33,5\% presentó traumatismo superficial no especificado de hombro y brazo. Los maltratos en ancianos están volviéndose cada vez más evidentes en la sociedad, adquiriendo una dimensión social y de la salud pública.

DESCRIPTORES: maltrato al anciano; violencia doméstica

\section{OCORRÊNCIA DE MAUS-TRATOS EM IDOSOS NO DOMICÍLIO}

O estudo teve como objetivo verificar a ocorrência de maus-tratos praticados nos domicílios contra idosos, de ambos os sexos, no ano 2006, em laudos de exame de corpo de delito e identificar os ofensores e tipos de lesões sofridas pelos mesmos, segundo a Classificação Internacional das Doenças (CID-10). A amostra constou de 87 idosos, de ambos os sexos, com idade de 60 anos ou mais, residentes no município de Ribeirão Preto, SP, que realizaram Boletim de Ocorrência nas Delegacias de Polícia, no ano 2002. Foram consultados laudos de exames de corpo de delito e a análise utilizada foi a estatística descritiva. Os maus-tratos no domicílio ocorreram com maior freqüência entre idosos do sexo masculino (58,6\%), que foram ofendidos por familiares como filhos, netos, genros e noras (47,1\%). Quanto ao tipo de lesões sofridas, 33,5\% apresentaram traumatismo superficial não especificado de ombro e braço. Os maus-tratos em idosos estão cada vez mais evidentes na sociedade, adquirindo dimensão social e de saúde pública.

DESCRITORES: maus-tratos ao idoso; violência doméstica

${ }^{1}$ RN, e-mail: cheila@eerp.usp.br; ${ }^{2}$ RN, Full Professor, e-mail: rosalina@eerp.usp.br. University of São Paulo at Ribeirão Preto College of Nursing, WHO Collaborating Centre for Nursing Research Development, Brazil 


\section{INTRODUCTION}

In Brazil, in the past five decades, an inversion in population characteristics has been observed, that is, there has been a decrease in birth and mortality rates, which leads to life extension. Estimates appoint that, by 2025 , the number of elderly in the country will amount to about 34 million, which will put them in the sixth place in the world ranking of countries with the highest number of people in this age group $^{(1)}$.

Populational aging is, nowadays, a world phenomenon and, due to this fact, in the past decades, societies have focused their attention on political, economic, cultural and health issues caused by this phenomenon.

As a consequence of the normal alterations triggered in the organism because of the aging process, many are the difficulties faced by the elderly; most of them result from their frailty and vulnerability, typical of their physiological status, which make them potential victims of growing social violence. In general, growing violence against the elderly population has become a broadly discussed issue in the scientific community, but actions against it are still fragile ${ }^{(2)}$.

The concepts of violence, maltreatment and abuse are often used with the same meaning and, even though people interpret them as physical aggression, there are significant cultural differences in several societies.

Since 1980 , violence has been recognized as a public health issue, not only from the physical trauma perspective, but also considering the several problems faced by individuals, which may affect their mental health. However, in the collective health area, in 1993, the World Health Organization ${ }^{(3)}$ defined violence as a disease or exernal cause of injury, as included in the International Classification of Diseases - ICD - 10 .

The Brazilian Ministry of Health ${ }^{(4)}$ uses the term intrafamiliar violence for any action or omission that impairs either the individual's well-being, physical or psychological integrity, or the freedom and right of plain development.

Violence can be performed in or outside the household by a family member, or even by people who happen to perform the parental function, even without blood bonds, but who maintain a power relationship with the other. Thus, the nature of the violent act can be physical, psychic, material, sexual, negligence and confinement.

It is important to point out that the family core is the main responsible for elderly well-being.
However, it is the State that should establish norms, rules or laws to protect against any type of abuse.

The family core is amplified with the definition of family arrangements that are important ways of care transference and support between generations, in which co-residence can provide higher member relationship exchanges, stimulate solidarity, aid, but also generate conflicts, leading to domestic maltreatment ${ }^{(5)}$.

In this sense, health professionals should debate maltreatment in order to create intervention proposals, so as to improve the diagnosis of maltreatment occurrence and of the family's social ideology.

There does not exist an analysis of the violence committed against the elderly, whether in institutions, shelters, hospitals and homes, nor of its effects on the victims' health ${ }^{(6)}$.

This study aimed to verify the occurrence of maltreatment performed at home against male and female elderly, in 2002, in medical legal exam reports at the Institute of Forensic Medicine in Ribeirão Preto, and to identify the offenders and types of injuries endured by the elderly, according to the International Classification of Diseases.

\section{METHODOLOGY}

The research subjects were all male and female elderly, aged 60 years or more, who filed charges against household maltreatment at police stations in Ribeirão Preto, in 2002. These maltreatments were sorted according to the International Classification of Diseases - ICD 10 referring to chapter XIX (S00 - T98), "injury, poisoning and certain other consequences of external causes" and chapter XX (V01 - Y98), "external causes of morbidity and mortality"(3).

The data collected in the medical legal exam reports included personal data, such as: initials, age, gender, ethnicity, marital status and procedence, as well as specific data about the maltreatment endured.

In the reports filed, most cases of maltreatment were classified as bodily harm. The difficulty in collecting data should be pointed out, taking into account that little information is presented in the records, but the information required for this study was present.

After data collection, a database was created in MS Excel, with double typing, for information reliability and posterior analysis in SPSS, version 8.9. 
This descriptive study was carried out after approval by the Institute of Forensic Medicine in Ribeirão Preto and the Ethics Committee at the University of São Paulo at Ribeirão Preto Medical School Hospital das Clínicas, authorization No 5513/2003.

\section{RESULTS}

Of 5233 registrations in the medical legal exam reports at the Institute of Forensic Medicine, in 2002, $175(3.2 \%)$ referred to study subjects, 100 (57.1\%) of whom lived in Ribeirão Preto and 75 $(42.9 \%)$ in other places. Of the 100 elderly people in Ribeirão Preto, $87 \%$ were reported to have been victims of maltreatment at home and 13 (13\%) victims of other forms of violence.

It was verified that most of the 87 elderly were between 60 and 69 years old, male and female, and were the greatest victims of maltreatment, totaling 60 (68.9\%) elderly people. Analyzing this age group, according to gender, it was observed that 33 (37.9\%) were men and 27 (31\%) women, a small gender difference.

Regarding marital status, only 84 records contained this information: 39 (46.4\%) were married or had a partner; 29 (34.5\%) widowed and 16 (19\%) single or divorced. For the widowed elderly, the number of maltreatment cases was practically the same, i.e. 15 (31.3\%) male and 14 (38.9\%) female victims.

Concerning the relationship between offender and victim, it was verified that $41(47.1 \%)$ elderly people specified the offender, among them children, grandchildren, daughters-in-law and sons-in-law; 20 $(22.9 \%)$ reported a friend or acquaintance; 15 $(17.2 \%)$ elderly people identified the offender as burglars who had broken into the house and 11 $(12.6 \%)$ reported the spouse or partner.

In relation to the severity of the assault, health care was needed at different levels, as represented in Table 1.

Table 1 - Distribution of records by the elderly victims of household maltreatment, according to gender and medical care level, Ribeirão Preto, SP, 2002

\begin{tabular}{lcccccc}
\hline \multirow{2}{*}{\multicolumn{1}{c}{ Care level }} & \multicolumn{2}{c}{ Male } & \multicolumn{2}{c}{ Female } & \multicolumn{2}{c}{ Total } \\
& $\mathbf{N}^{\mathbf{2}}$ & $\%$ & $\mathbf{N}^{\circ}$ & $\%$ & $\mathbf{N}^{\circ}$ & $\%$ \\
\hline Did not seek care & 28 & 54.9 & 22 & 61.1 & 50 & 57.5 \\
Primary & 18 & 35.3 & 9 & 25 & 27 & 31 \\
Secondary & 2 & 3.9 & - & - & 2 & 2.3 \\
Tertiary & 3 & 5.9 & 5 & 13.9 & 8 & 9.2 \\
Total & 51 & 100 & 36 & 100 & 87 & 100 \\
\hline
\end{tabular}

Table 1 shows that, even though most elderly, $50(57.4 \%)$, did not seek medical care for the maltreatments endured, there was a high percentage that required care, according to records in the medical report. The records show that the appointments took place at secondary level - hospital, when the injury was more complex, such as fractures and burns.

Concerning the injuries endured by the elderly, according to their descriptions, they were grouped into 11 codes for diseases, in line with the ICD-10. Among those who sought care, only 2 (2.3\%) men did not show apparent injuries.

The type and number of endured injuries, according to gender, are shown in Tables 2 and 3 .

Table 2 - Distribution of the elderly who endured household maltreatment, according to gender and endured injury, ICD-10, Ribeirão Preto, SP, 2002

\begin{tabular}{|c|c|c|c|c|c|c|}
\hline \multirow{3}{*}{ Injury 1 (ICD-10) } & \multicolumn{6}{|c|}{ Gender } \\
\hline & \multicolumn{2}{|c|}{ Male } & \multicolumn{2}{|c|}{ Female } & \multicolumn{2}{|c|}{ Total } \\
\hline & $\mathbf{N}^{\circ}$ & $\%$ & $\mathbf{N}^{\circ}$ & $\%$ & $\mathbf{N}^{\circ}$ & $\%$ \\
\hline (S00.1) eyelid and periocular region contusion & 10 & 19.6 & 5 & 13.8 & 15 & 17.2 \\
\hline (S00.8) superior injuries of other parts of the head & 5 & 9.8 & 4 & 11.1 & 9 & 10.3 \\
\hline (S01.9) non-specified injury in the head & 4 & 7.8 & 2 & 5.5 & 6 & 6.8 \\
\hline (S02.9) fracture of skull and facial bones, non-specified parts & 1 & 1.9 & 1 & 2.7 & 2 & 2.2 \\
\hline (S22.0) fracture of vertebra & - & - & 1 & 2.7 & 1 & 1.1 \\
\hline (S40.9) shoulder and arm non-specified superior injury & 16 & 31.3 & 16 & 44.4 & 32 & 36.7 \\
\hline (T00.9) non-specified multiple superior injury & 10 & 19.6 & 2 & 5.5 & 12 & 13.7 \\
\hline (T30.0) burn of unspecified body region & 1 & 1.9 & 1 & 2.7 & 2 & 2.2 \\
\hline (T74.2) sexual abuse & - & & 1 & 2.7 & 1 & 1.1 \\
\hline (74.3) psychological abuse & - & - & 1 & 2.7 & 1 & 1.1 \\
\hline (Y00) assault by blunt object & 2 & 3.9 & 2 & 5.5 & 4 & 4.5 \\
\hline Absence & 2 & 3.9 & - & - & 2 & 2.2 \\
\hline Total & 51 & 100 & 36 & 100 & 87 & 100 \\
\hline
\end{tabular}


To demonstrate the most recurrent type of injury, 32 (36.7\%) male and female elderly were victims of non-specified superficial shoulder and arm injury. Only two (3.9\%) men did not endure apparent injuries. There was $1(2.7 \%)$ case of sexual abuse among female victims, and injuries like eyelid and periocular region contusion were twice as frequent among male victims.

Table 3 - Distribution of the elderly who endured household maltreatment, according to gender and multiple injuries, ICD-10, Ribeirão Preto, SP, 2002

\begin{tabular}{|c|c|c|c|c|c|c|}
\hline \multirow{3}{*}{ Injury 2 (ICD-10) } & \multicolumn{6}{|c|}{ Gender } \\
\hline & \multicolumn{2}{|c|}{ Male } & \multicolumn{2}{|c|}{ Female } & \multicolumn{2}{|c|}{ Total } \\
\hline & $\mathbf{N}^{\circ}$ & $\%$ & $\mathbf{N}^{\circ}$ & $\%$ & $\mathrm{~N}^{\circ}$ & $\%$ \\
\hline $\begin{array}{l}\text { (S00.8) superior injuries of other } \\
\text { parts of the head }\end{array}$ & 1 & 1.9 & - & - & 1 & 1.1 \\
\hline $\begin{array}{l}\text { (S01.9) non-specified injury in the } \\
\text { head }\end{array}$ & 3 & 5.8 & 4 & 11.1 & 7 & 8.0 \\
\hline $\begin{array}{l}\text { (S02.9) fracture of skull and facial } \\
\text { bones, non-specified parts }\end{array}$ & - & - & 1 & 2.7 & 1 & 1.1 \\
\hline $\begin{array}{l}\text { (S40.9) non-specified superficial } \\
\text { shoulder and arm injury }\end{array}$ & 4 & 7.8 & 4 & 11.1 & 8 & 9.1 \\
\hline $\begin{array}{l}\text { (T00.9) multiple non-specified } \\
\text { superficial injury }\end{array}$ & 8 & 15.6 & 4 & 11.1 & 12 & 13.7 \\
\hline Absence & 35 & 68.6 & 23 & 63 & 58 & 66.6 \\
\hline Total & 51 & 100 & 36 & & 87 & \\
\hline
\end{tabular}

In the sample of 87 elderly, $29(33.3 \%)$ showed more than one type of injury, 16 (31.3\%) men and 13 (36.1\%) women. The multiple nonspecified superficial injuries were seen as another injury in $12(13.8 \%)$ elderly, being $8(15.6 \%)$ men and $4(11.1 \%)$ women.

\section{DISCUSSION}

The main complaint reported in the police reports indicates physical violence against the elderly at home. In a previous survey, performed with reports from police stations in the city of São Paulo, in 1998, which aimed to investigate homicide in the female population, countless gaps were found in these occurrence records, making data collection difficult. Twelve percent of the homicides or attempts were supposed to know the offenders' responsibility ${ }^{(7)}$.

A study carried out among 208 elderly in the city of Ribeirão Preto, SP, with 119 women and 89 men, to identify maltreatment they had endured in the period from 1994 to 1998, demonstrated an expressive gender difference in maltreatment. This study stands out in national literature for referring to the elderly who endured maltreatment and filed complaints at police stations, being afterwards sent for medical legal examination at the Institute of Forensic Medicine ${ }^{(8)}$. It was observed that five years of maltreatment complaints against the elderly reported in the IFM had originated 208 police reports, with an average of 41 reports per year. However, in the present study, when the police reports in 2002 were evaluated, there were 175 reports.

When the two studies are compared, some hypotheses appear to justify the increase in elderly complaints. One of them refers to their awareness of their rights and life values, or still, that the complaints could have been reported by independent elderly, with autonomy to pursue legal means and denounce maltreatment, as well as the offender. There is also the likelihood of an increase in assault cases, thus elevating notification figures.

On a global scale, the first studies on maltreatment against the elderly show that most victims were older women, with physical or mental disabilities, dependent on the family or care-giver, and they, who were, in most cases, the agents of the assault ${ }^{(9)}$. Compared with the present study, it can be identified that elderly men are also violence victims. Therefore, both genders are subject to this social issue.

The characterization of offenders by national and international researchers ${ }^{(8-12)}$ showed the following signs of vulnerability and risk: the offender lives in the same house as the victim; financially-dependent children with parents of advanced age; elderly dependent on family and children for subsistence; alcohol and drug abuse performed by children or the elderly; social isolation of the family or elderly people, history of previous aggression against the elderly and history of violence in the family. These data show greater vulnerability to social issues among the elderly, which was also confirmed in the present study.

According to the Elderly Statute ${ }^{(6,13)}$ art. 4, "no elderly will be object of any type of negligence, discrimination, violence, cruelty or oppression and any attack to their rights, due to action or omission, will be punished in the form of law". Besides the Elderly Statute, every citizen should be respected. Thus, when the elderly seek medical care in case of aggression, it is extremely important that health professionals, including nurses, know how to identify the event, attempting to search solutions for the maltreatment problem and negligence. Emergency services and local health centers deserve attention, because they end up receiving most of the maltreatment victims. 
In this context, some questions arose: how is professional training to deal with the family? Are there legal resources to assist the victim? Who are the people responsible for continuous care delivery to the victim? How is society organized for this care? Are there investments in research to conceptualize maltreatments, abuses, violence, to define which measures and concepts are being researched?

Another question to be debated refers to the support given to families so that they can take care of the elderly. This is not only theirs, but also society's responsibility in general. A declaration of elderly rights represents, inquestionably, an important advance. However, a social support network to make such rights effective is indispensable ${ }^{(14)}$. Priority attention should be given to the political decision to turn elderly human rights in Brazil universal, since the population growth has accelerated ${ }^{(14)}$. It should be pointed out that the author's understanding of social support refers to governmental and non-governmental social institutions.

In order to face the issue of maltreatment against the elderly, whether or not in the household, it is evident that an integrated care network needs to be built, involving different institutions, constituting a social support network, with special attention to education, health, justice, security, culture and governmental and non-governmental organizations.

Another aspect to be contemplated refers to public service records, such as police and medical legal exam reports. The professionals involved should attribute greater attention to these records, because the information they contain can offer more details, with a view to further research in the area.

The researchers' concern when carrying out this study was to demonstrate that maltreatment cases against the elderly have been increasing, something that can be prevented and avoided. Even though it is not a new subject, it has been raising the Brazilian society's awareness and has turned into a social issue. It should be included in public policies and also receive greater attention from families.

Health professionals should be prepared to diagnose suspect or confirmed maltreatment cases, in order to work with the elderly and inform them about health damages, possible conducts and their rights.
In view of these study results, further studies are needed about maltreatment risk assessment, multi-professional care needs to be implemented and research should be developed that can contribute to the creation of public policies to minimize problems of elderly maltreatment.

\section{FINAL REMARKS}

Thus, the implications related to practices, policies and research on maltreatment against the elderly should be pondered, so as to allow nursing professionals to obtain broader knowledge, with a view to detecting suspect or confirmed cases, in which they will:

- Use instruments to assess maltreatment risks;

- Review the family and medical history;

- Assess the elderly people's financial, physical and psychological situation, including a sexual evaluation; - Along with an interdisciplinary team, proceed with the family, due to the fact that the nursing role in the team is fundamental for the development of care. Nurses should know the patient's family history, perform physical exams and analyze these data to perform nursing interventions;

- Offer social support to the families of victimized elderly people, with the help of governmental and non-governmental organs, focusing on family education to minimize the elderly maltreatment;

- Enable other nurses to accomplish the role of defending elderly rights, whether by detecting maltreatment or performing closer family monitoring;

- Develop studies that look at maltreatment against the elderly in different communities, applying several methodologies and instruments for comparative analysis;

- Disseminate maltreatment research to academic and non-academic communities and governmental organs, to plan intervention strategies in teams, and create awareness of problems and rights;

- Link research results and public policies, aiming to proceed with health promotion and prevention and care delivery to elderly victims of maltreatment;

- Explore the Brazilian culture, social attitudes and health systems with regard to aging. 


\section{REFERENCES}

1. Ministério da Saúde [homepage na Internet] Brasília: Ministério da Saúde; [Acessado 2002 abril 14]. Instituto Brasileiro de Geografia e Estatística. Censo 2000. Disponível em: http:// ibge.gov.br/home/estatística/população/ perfilidoso/perfilidosos 2000.pdf.

2. Silveira R, Rodrigues RAP, Costa Júnior ML. Idosos que foram vítimas de acidentes de trânsito no município de Ribeirão Preto-SP, em 1998. Rev Latino-am Enfermagem 2002 novembro-dezembro; 10(6): 765-71.

3. Organização Mundial da Saúde. Classificação Internacional das Doenças. Tradução do Centro Colaborador da OMS para a Classificação de Doenças em Português. ga ed. Revisada. São Paulo: EDUSP; 2003.

4. Ministério da Saúde (BR). Secretaria de Políticas de Saúde. Violência intrafamiliar: orientações para prática em serviço. Cadernos de Atenção Básica 8. Brasília (DF): Ministério da Saúde; 2002.

5. Camarano AA, Ghaouri SKE. Famílias com idosos: ninhos vazios? Texto para discussão 950. Rio de Janeiro: IPEA; 2003.

6. Minayo MCS. Violência: um velho-novo desafio para a atenção à saúde. Rev Bras Ed Médica 2005 abril; 29(1): 5563.

7. Blay E. A Violência contra a mulher e políticas públicas. Estudos Avançados USP 2003; 17(49):87-96.

8. Menezes MR. Da violência revelada à violência silenciada: um estudo etnográfico sobre a violência doméstica contra o idoso. Ribeirão Preto. [tese doutorado]. Ribeirão Preto (SP): Escola de Enfermagem de Ribeirão Preto/USP; 1999.

9. Wolf RS. Maltrato del anciano. In: Perez EA, Galinsky D, Martinez FM, Salas AR, Ayendez MS. La atencion de los ancianos: un desafio para los años noventa. Washington: OPS; 1995. p. 35-42.

10. Ortmamn C, Fechner G, Bajanowski T, Brinkman B. Fatal neglect of the elderly. Journal of Legal Medicine 2001; 114(3):191-3.

11. Sanmartin R, Torner A, Marti N, Izquierdo P, Solé C, Torrelas R. Violência doméstica: prevalência de sospecha de maltrato a ancianos. Atención Primaria 2001; 27(5):331-4. 12. Reay AM, Browne KD. Risk factor characteristics in carers who phiysically abuse or neglet their elderly dependants. Aging Mental Health 2001; 5(1):56-62.

13. Estatuto do Idoso: dispositivos constitucionais pertinentes. Lei $n^{\circ} 10.741$ de $1^{\circ}$ de outubro de 2003 , normas correlatas, índice temático. Brasília: Senado Federal. Subsecretaria de Edições Técnicas; 2003.

14. Minayo MCS. Violência contra idosos: o avesso do respeito à experiência e à sabedoria. Brasília (DF): Secretaria Especial dos Direitos Humanos; 2004. 